\title{
On the Thought of the Training Mode of Open English Talents
}

\author{
Yana Liu \\ Xinxiang College. China \\ 1654230295@qq.com
}

Keywords: open English talents; professional development; lifelong education

\begin{abstract}
Lifelong education concept is the basis of the basic human survival quality. "Never too old to learn" is the concentrated reflection and the basic thought connotation of lifelong learning education concept, is also the essential spirit main line and conception for teachers to teach and for students to learn. The development of the society has put forward new request for English teachers and students. The teachers must continuously adjust their knowledge structure and teaching behavior according to the new talent standard, taking fostering open English talents as the goal, changing ideas, providing lasting power for the sustainable development of the students and themselves.
\end{abstract}

\section{The Connotation of the Open English Talents}

Education is the foundation of national economic development and national rejuvenation, it is an important part of higher education decision-making in our country to develop the higher education and improve the quality of higher education. With the rapid development of global politics and economy, English has increasingly brought the attention of the people all over the world as a common international language, serving as an invisible bridge for international communication. Since China's accession to the WTO, there are increasingly frequent international exchanges with growing demand for new type of high quality English talents.

The 2000 revision of the National English-teaching Curriculum for English Majors in Universities (the NECEMU) points out that institutions of higher learning for English majors should cultivate English language talents with a solid English language foundation and extensive cultural knowledge and who can use English skillfully in foreign affairs, education, economy and trade, culture, science and technology, military and other departments engaged in translation, teaching, management and research. In the process of the evolution of English talents training target, many targets have been raised as "compound" English talent, "international" English talents, English talents "innovative" and "open" English talents and so on. To distinguish the four terms have no practical significance in English education and teaching .Although they can't entirely equivalent with different titles, they have the same effect."Open" fusion "composite" and the inherent characteristics of the "innovative", refers to opening to the outside world, adapting as circumstances change, constantly adjusting knowledge structure and updating the content as the change of domestic and international society. So the term makes innovation and renewable more outstanding.

In the new century, qualified "open" English talents are no longer the traditional teaching under the guidance of traditional education, who can only memorize English words and grammar rules, and who can only do mechanical practice to get high scores, but those have obvious characteristics of the open language talent. New type of talents have broad basic and professional knowledge and solid basic and professional skills, with strong comprehensive quality. Also they will be able to update professional knowledge, and should have strong ability of social communication, organization and management, innovation and intercultural communication, etc.

The original curriculum before revision focused on the cultivation of the "advanced English talents", emphasizing that the core of cultivation of English talents is grasping professional language, and the revised one takes "compound English talents and open English talents" as the core, and gives more emphasis on the ability to adapt to social development of students and graduates of English major and puts forwards high requirements for them in humanities accomplishment, professional accomplishment and so on. 


\section{The Evolution of English Talents Training Target and the Demands of Students}

In a period of time after the founding of New China in1949, English teaching development was slow and in trouble. In the mid-1960s, English gradually occupied the main body status, with an increasing number of English major students year by year. Due to less chance for students to have face-to-face communication with foreigners, they were in an almost totally closed study atmosphere, coupled with the backward teaching methods, the teaching quality was not high. English teaching methods and learning ways mainly inherited the Chinese traditional personnel training mode: be oblivious of the outside world, of one mind only. Learners hold mentality of "claptrap, high hung", separating their own language learning from the development of social politics, economy and culture, so that they were only good at reading aloud to recite the book of knowledge, but not good at innovation, active learning, also they neglected the principles of Marxist "theory contact practice" and the basic skills of English, causing phenomenon as "deaf English" and "dumb English".

In 1978, the Third Plenary Session of the Eleventh CPC Central Committee made a major decision of China's reform and opening-up, thus great changes have taken place in all walks in China. Marxist theory holds that: social being determines social consciousness, the latter is the reflection of the former, and the features and change of social existence decides that of social consciousness. Since China's reform and opening up, great changes have taken place in the social economic structure, which requires the corresponding change in the superstructure. Education as one of the superstructure areas should also be adjusted. Since entering 21st century, with the rapid development of international politics and economy, English has become an important resource for political and economic development instead of a communication tool[1]. The international economic globalization makes the internationalization of talent activities, which poses new challenges for the cultivation of English talents in our country. The traditional English education structure and personnel training mode no longer adapt to the needs of economic development. Cultivation of compound and open English talents training has become the theme of the higher English education in new area.

Cultivating open English talents proposes new requirements not only for college talent cultivation mode and structure, but also for the development of English major students. Previous syllabus and curriculum standard only focuses on the improvement of students' English basic skills and professional knowledge of English learning, ignoring the related knowledge of humanities, science and technology knowledge, lacking study of specialty knowledge related to the future work after the graduation. They do not pay attention to training the students' ability in acquiring knowledge, independent thinking, social communication, organizing and managing, cross-cultural communication and innovation. Furthermore, they ignores the students' ideological and moral quality, cultural quality and the cultivation of the psychological quality. Graduates trained in this model will not be able to meet the needs of work and social development, for what they "learned" and "used" are disconnected, and they lack knowledge, ability and quality related to work, so they can not quickly fit into the workplace, bringing tangible and intangible influence to their own self-esteem and unit development, causing the decline in employment for graduates in English.

On the basis of their own interests, the English major freshmen should learn the professional positioning, professional characteristics of their major, and know the including courses and potential job positions of their major and have an idea of the knowledge, ability and quality they should have, etc. With a good understanding the connotation and characteristics of the open English talents, they should make study goal and plan in the future four years. Through various classroom learning activities and extracurricular activities to exercise their own ability. Seize every practice opportunity to apply the theory of knowledge to the specific practice, learn to prepare for future work. On the one hand, students should completely change the passive learning habit that learning under the guidance of teachers in original high school, and form the autonomous conscious learning habit; On the other hand, they should abandon pure rigid rote memorization of grammar exercises, using a variety of ways to achieve maximum control of language. 


\section{To Perfect the Training Mode of Open English Talents and Promote the English Teachers' Professional Development}

As a special professional group, college English teachers take the important tasks as developing new open talents with high quality and international vision. With English major graduates enter the society annually, employers and society have paid more and more attention to the scientific and reasonable forming of university English professional, followed by the whole society's highlight on the professional quality of college English teachers. Sukhomlinskii argues that the time of teachers' labor and creation is like a river, which depends on many small streams to nourish it. Teachers should often read, the more accumulation of knowledge, the more relaxed in classes. The teacher's knowledge structure and the knowledge system needs to be constantly updated, and the teachers' ability and quality should be constantly advanced and improved.

Under the guidance of the new talents training target, college English teachers will face both opportunities and challenges for their work and other fields in teaching will reform a lot. The reform contents involves teaching ideas, teaching principles, culture of education, education evaluation and various aspects. The core of reform focuses on the sustainable development of both teachers and students, and the target of reform is to produce more open English talents to adapt to the social development.The theoretical foundation of the sustainable development of teachers and students is a concept of life-long education, also the open English talents cultivation also implied the concept of life-long education. Lifelong education is not only the demand of social development for individual, but also the requirement of education reform for teachers' professional role. Lifelong education is based on lifelong education and training, it is not confined to education in university, it begins at the beginning of life and ends at the end of life. Including the all periods of education and training, it refers to all the education and training received by individuals from birth to death[2]. To cultivate students into life-long learners and open English talents, teachers first must be a lifelong learner and suitable English talents themselves.

College English teachers' professional learning and development should not stop when they get a certificate, but should continue to the end of life. The certificate they hold is not equal to ability. Only through persistent learning activities can teachers' original knowledge increase, ability and quality continuously improve. "Be insatiable in learning and teaching" means that teachers acquire lifelong learning ability and then they can teach students learn to lifelong learning, this is the so-called good example is the best sermon. Teachers should do their part to have in-depth understanding of the connotation and characteristics of the open English talents, based on which continuously adjust and update their knowledge, improve ability and quality. What's more, they should take an active part in all kinds of professional training in the field of training and social related to raise awareness of the education of the open English talent cultivation and education ability, to enhance their professional development consciousness, At the same time, they ought to adjust the teaching material content and teaching methods according to market demand and practical standards. Through this, they have the characteristics of the open English talents, and then subtly influence and guide the student to do so.

For teachers, to become lifelong learners and open English talents is the need of social development and progress of science and technology, is also the inherent requirement of teachers. To survive, teachers must take development as the first priority. Teacher professional development is the lifeline of college English teachers' professional live. This is not only the need of individual English teacher, which meets their personal life value and self-fulfillment, but the needs of the parents, universities, students and even the society as a whole, namely construction of a learning society with lifelong learning for everyone and the needs of building a harmonious society. Lifelong education and open education can promote individual teacher and student growth, can also open an important way for rejuvenating China with science and education, can further provide new contents and forms for teacher professional development . 


\section{References}

[1]. Wang Ruqin. Requirement for High Quality Foreign Language Talents since China's Accession to WTO[J]. Journal of Henan Financial Management Cadre College, 2003, (5).

[2]. Xu Runhua. Exploration of Some Hot Issues of Curriculum and Teaching Reform in Primary and Middle Schools in Our Country[M]. Beijing: Archives Press of China, 2006. 